\title{
High denitrification and anaerobic ammonium oxidation contributes to net nitrogen loss in a seagrass ecosystem in the central Red Sea
}

\author{
Neus Garcias-Bonet ${ }^{1}$, Marco Fusi ${ }^{1}$, Muhammad Ali $^{2}$, Dario R. Shaw ${ }^{2}$, Pascal E. Saikaly ${ }^{2}$, Daniele Daffonchio ${ }^{1}$, and \\ Carlos M. Duarte ${ }^{1}$ \\ ${ }^{1}$ King Abdullah University of Science and Technology, Red Sea Research Center, Thuwal 23955-6900, Saudi Arabia \\ ${ }^{2}$ King Abdullah University of Science and Technology, Water Desalination and Reuse Center, \\ Thuwal 23955-6900, Saudi Arabia
}

Correspondence: Neus Garcias-Bonet (neus.garciasbonet@kaust.edu.sa)

Received: 17 July 2018 - Discussion started: 19 July 2018

Revised: 30 October 2018 - Accepted: 27 November 2018 - Published: 11 December 2018

\begin{abstract}
Nitrogen loads in coastal areas have increased dramatically, with detrimental consequences for coastal ecosystems. Shallow sediments and seagrass meadows are hotspots for denitrification, favoring $\mathrm{N}$ loss. However, atmospheric dinitrogen $\left(\mathrm{N}_{2}\right)$ fixation has been reported to support seagrass growth. Therefore, the role of coastal marine systems dominated by seagrasses in the net $\mathrm{N}_{2}$ flux remains unclear. Here, we measured denitrification, anaerobic ammonium oxidation (anammox), and $\mathrm{N}_{2}$ fixation in a tropical seagrass (Enhalus acoroides) meadow and the adjacent bare sediment in a coastal lagoon in the central Red Sea. We detected high annual mean rates of denitrification $(34.9 \pm 10.3$ and $\left.31.6 \pm 8.9 \mathrm{mg} \mathrm{N} \mathrm{m}^{-2} \mathrm{~d}^{-1}\right)$ and anammox (12.4 \pm 3.4 and $\left.19.8 \pm 4.4 \mathrm{mg} \mathrm{N} \mathrm{m}^{-2} \mathrm{~d}^{-1}\right)$ in vegetated and bare sediments. The annual mean $\mathrm{N}$ loss was higher (between 8 and 63fold) than the $\mathrm{N}_{2}$ fixed (annual mean $=5.9 \pm 0.2$ and $0.8 \pm$ $0.3 \mathrm{mg} \mathrm{N} \mathrm{m}^{-2} \mathrm{~d}^{-1}$ ) in the meadow and bare sediment, leading to a net flux of $\mathrm{N}_{2}$ from sediments to the atmosphere. Despite the importance of this coastal lagoon in removing $\mathrm{N}$ from the system, $\mathrm{N}_{2}$ fixation can contribute substantially to seagrass growth since $\mathrm{N}_{2}$ fixation rates found here could contribute up to $36 \%$ of plant $\mathrm{N}$ requirements. In vegetated sediments, anammox rates decreased with increasing organic matter (OM) content, while $\mathrm{N}_{2}$ fixation increased with $\mathrm{OM}$ content. Denitrification and anammox increased linearly with temperature, while $\mathrm{N}_{2}$ fixation showed a maximum at intermediate temperatures. Therefore, the forecasted warming could further increase the $\mathrm{N}_{2}$ flux from sediments to the atmosphere, potentially impacting seagrass productivity and
\end{abstract}

their capacity to mitigate climate change but also enhancing their potential $\mathrm{N}$ removal.

\section{Introduction}

Nutrient supply is an important driver of marine primary production (Field et al., 1998; Howarth, 1988), where nitrogen (N) availability is believed to exert a key role in regulating net primary production (Howarth, 1988) and driving eutrophication (Howarth and Marino, 2006) in coastal ecosystems. Anthropogenic activities have led to a doubling of the global amount of fixed N, with important changes in ecosystem productivity, diversity, air quality, and, ultimately, climate (Fowler et al., 2013; Vitousek et al., 1997). Whereas natural atmospheric dinitrogen $\left(\mathrm{N}_{2}\right)$ fixation is globally estimated at $203 \mathrm{Tg} \mathrm{N} \mathrm{yr}^{-1}$ (from which $140 \mathrm{Tg} \mathrm{N} \mathrm{yr}^{-1}$ occurs in marine systems), the anthropogenic contribution to new $\mathrm{N}$ supply has been estimated at $210 \mathrm{Tg} \mathrm{N} \mathrm{yr}^{-1}$, mainly produced by $\mathrm{N}_{2}$-fixing crops, combustion of fossil fuels, and the Haber-Bosch industrial reaction (Fowler et al., 2013).

Coastal areas receive high inputs of fixed $\mathrm{N}$ by river and groundwater discharges and atmospheric deposition (Galloway et al., 2003; Voss et al., 2013), causing severe problems related to eutrophication and, potentially, dystrophic crisis (Galloway et al., 2003; Herbert, 1999). High N inputs can be partially balanced through losses, as coastal marine sediments are hotspots of denitrification (Devol, 2015), the conversion of nitrates and nitrites to $\mathrm{N}_{2}$ (and $\mathrm{N}_{2} \mathrm{O}$ partially), leading to the loss of fixed N. Globally, coastal denitrifica- 
tion has been estimated to range from 4 to $8 \mathrm{Tg} \mathrm{N} \mathrm{yr}^{-1}$ (Voss et al., 2013), which is modest compared to the global riverine input of $66 \mathrm{Tg} \mathrm{N} \mathrm{yr}^{-1}$ (Seitzinger et al., 2005), $\mathrm{N}_{2}$ fixation of about $15 \mathrm{Tg} \mathrm{N} \mathrm{yr}^{-1}$ (Voss et al., 2013), and atmospheric deposition of $1 \mathrm{Tg} \mathrm{N} \mathrm{yr}^{-1}$ (Voss et al., 2013) to the coastal ocean. Recently, however, anaerobic ammonium oxidation (anammox), the chemoautotrophic conversion of ammonium and nitrite to $\mathrm{N}_{2}$, has also been regarded as an important process in marine sediments. It has been estimated to account for from nearly zero up to $80 \%$ of the total $\mathrm{N}$ loss in sediments (Dalsgaard et al., 2005; Devol, 2015).

Within the coastal ocean, seagrass ecosystems support high rates of $\mathrm{N}_{2}$ fixation (McGlathery, 2008), particularly in tropical and subtropical ecosystems (Welsh, 2000; Herbert, 1999). Nitrogen supplied by $\mathrm{N}_{2}$ fixation can account for up to $90 \%$ of plant nutrient requirements (Hansen et al., 2000). It has been suggested that seagrasses have a close mutualistic relationship with $\mathrm{N}_{2}$-fixing bacteria inhabiting the rhizosphere (Herbert, 1999) and roots (Garcias-Bonet et al., 2016), where bacteria would benefit from root exudates and plants would benefit from fixed N supply. However, seagrass ecosystems also support high denitrification rates (Eyre et al., 2011b) and have been identified as key habitats for $\mathrm{N}$ loss in temperate (Eyre et al., 2016) and subtropical (Eyre et al., 2011a) estuaries. Although anammox rates have not been assessed for seagrass sediments as yet, Salk et al. (2017) recently reported very low anammox rates $\left(0.18 \mu \mathrm{mol} \mathrm{N} \mathrm{m} \mathrm{m}^{-2} \mathrm{~h}^{-1}\right)$, despite accounting for $74 \%$ of $\mathrm{N}$ loss, on bare sediment adjacent to a Zostera muelleri meadow in a sub-tropical estuarine system. Therefore, the role of seagrass ecosystems as net sinks or sources of $\mathrm{N}$ remains unclear. Welsh et al. (2000) reported very low denitrification rates compared to $\mathrm{N}_{2}$ fixation rates in a temperate intertidal seagrass meadow, whereas denitrification seems to exceed $\mathrm{N}_{2}$ fixation in tropical (Alongi et al., 2008) and sub-tropical (Eyre et al., 2011a) seagrass ecosystems. The balance between transformations of inert atmospheric $\mathrm{N}_{2}$ and reactive $\mathrm{N}$ in seagrass ecosystems is an important driver of their net $\mathrm{N}$ budget (Hemminga et al., 1991), particularly in areas with limited $\mathrm{N}$ inputs from land. This is the case for seagrass meadows in arid regions lacking riverine inputs, such as the Red Sea, characterized by general oligotrophic conditions in surface waters (Raitsos et al., 2013; Weikert, 1987).

Nitrogen cycling in seagrass ecosystems is mediated by complex microbial communities requiring specific physicochemical conditions, which may ultimately determine the balance between transformations of inert atmospheric $\mathrm{N}_{2}$ and reactive N. Seagrass meadows offer patchy sediment conditions, affected by the release of organic exudates and oxygen by seagrass roots (Pedersen et al., 1998), as well as the activity of burrowing infauna, which facilitates the exchange and diffusion of nutrients and allows the oxygenation of deep sediment layers (Welsh, 2003). These processes contribute to high spatial heterogeneity in seagrass sediments, therefore, modifying the redox potential (Enriquez et al., 2001) and al- lowing for the co-occurrence of processes requiring different environmental conditions (Herbert, 1999; Hemminga et al., 1991).

Here, we test the following hypotheses: (i) that seagrasses and bare sediments in a coastal lagoon in the Red Sea are net $\mathrm{N}_{2}$ sources and (ii) that the loss of reactive $\mathrm{N}$ from sediments to the atmosphere increases with temperature. Specifically, we assess the annual balance between losses of reactive $\mathrm{N}$ as $\mathrm{N}_{2}$, via denitrification and anammox, and gains of reactive $\mathrm{N}$, by $\mathrm{N}_{2}$ fixation, in a tropical seagrass (Enhalus acoroides) meadow and the adjacent bare sediment in a coastal lagoon located in the central Red Sea. We first describe the environmental conditions in the sediments, based on microprofiles of oxygen $\left(\mathrm{O}_{2}\right)$, sulfide $\left(\mathrm{H}_{2} \mathrm{~S}\right)$, and redox, and then evaluate denitrification, anammox, and $\mathrm{N}_{2}$ fixation rates in seagrass sediments and adjacent bare sediments. In addition, we analyze the thermal dependence of denitrification, anammox, and $\mathrm{N}_{2}$ fixation throughout the annual in situ thermal range. The Red Sea is one of the warmest seas and is warming faster than other seas (Chaidez et al., 2017), thereby offering an opportunity to assess if the balance between losses of reactive $\mathrm{N}$ as $\mathrm{N}_{2}$, via denitrification and anammox, and gains of reactive $\mathrm{N}$ by $\mathrm{N}_{2}$ fixation, may be affected by warming.

\section{Materials and methods}

\subsection{Study site}

The study was conducted on an Enhalus acoroides seagrass meadow in Khor Almesena'a, a shallow enclosed coastal lagoon located in the central Red Sea $\left(22^{\circ} 23^{\prime} 23.2^{\prime \prime} \mathrm{N}\right.$, $\left.39^{\circ} 08^{\prime} 08^{\prime \prime} \mathrm{E}\right)$. The study site was a monospecific seagrass meadow at $2 \mathrm{~m}$ depth and the adjacent (about $5 \mathrm{~m}$ from the edge of the seagrass meadow) bare sediment. The study was conducted between June 2016 and April 2017. We assessed sediment microprofiles $\left(\mathrm{O}_{2}, \mathrm{H}_{2} \mathrm{~S}\right.$, and redox $)$ and denitrification, anammox, and $\mathrm{N}_{2}$ fixation rates across five sampling events, two in summer (June and August 2016), one in the fall (November 2016), one in winter (February 2017), and one in spring (April 2017). At each sampling time, we also monitored and recorded salinity and seawater temperature in situ every $10 \mathrm{~min}$ for $24 \mathrm{~h}$ using an EXO1 Multiparameter Sonde (YSI, USA).

\subsection{Sediment microprofiles}

At each sampling event, we performed $\mathrm{O}_{2}, \mathrm{H}_{2} \mathrm{~S}$, and redox microprofiles on vegetated sediments and adjacent bare sediment reaching an average depth of $7 \mathrm{~cm}$ below the sediment surface, using the field microprofiling system by Unisense (Aarhus, Denmark). At each sampling event, we collected four sediment cores $(40 \mathrm{~cm}$ in length and $10 \mathrm{~cm}$ in diameter, two replicate cores per each sediment type) containing at least $15 \mathrm{~cm}$ of undisturbed sediment. The cores were transported immediately to the laboratory and the micropro- 
file analysis started within the next $3 \mathrm{~h}$. Oxygen microsensors (Ox-200), with a tip diameter of $200 \mu \mathrm{m}$, were calibrated in sterile water at oxygen partial pressures of 0 and $21 \mathrm{kPa}$. For $\mathrm{H}_{2} \mathrm{~S}$ measurements, we used $\mathrm{H}_{2} \mathrm{~S}-200$ microelectrodes $(200 \mu \mathrm{m}$ tip diameter $)$. Calibration of the microsensors was performed following manufacturer specifications and following Seitaj et al. (2015). Redox measurements were performed using Redox-200 microelectrodes ( $200 \mu \mathrm{m}$ tip diameter). The electrode potential in the sediment was measured against the Unisense $\mathrm{Ag}-\mathrm{AgCl}$ reference electrode and the calibration was performed using two quinidrone solutions $\left(10 \mathrm{mg} \mathrm{mL}^{-1}\right)$ buffered at $\mathrm{pH} 4$ and 7, respectively. Microsensors were positioned using a manual micromanipulator (Märzhäuser, Wetzlar, Germany), and the tip position was visually controlled with a horizontally mounted USB stereomicroscope (Veho VMS-004). Oxygen, $\mathrm{H}_{2} \mathrm{~S}$, and redox microprofiling measurements started $10 \mathrm{~min}$ after embedding and lasted about $4 \mathrm{~h}$ per sediment core. The sediment surface position was adjusted using the software Sensor Trace Suite v2.7.100 (Unisense, Aarhus, Denmark). The microprofiles were performed under light and dark conditions per triplicate. The cores were left for $12 \mathrm{~h}$ under dark conditions before starting the microprofiles under dark conditions.

\subsection{Denitrification and anammox rates}

We measured denitrification and anammox rates with a batch incubation experiment with ${ }^{15} \mathrm{~N}$-labeled nitrogen compounds in vegetated sediment and the adjacent bare sediment. At each sampling event, we collected six cylindrical plastic cores $(40 \mathrm{~cm}$ length and $5 \mathrm{~cm}$ in diameter, three replicate cores per each sediment type) containing at least $15 \mathrm{~cm}$ of undisturbed sediment. The cores were transported immediately to the laboratory. Denitrification and anammox rates were measured at three sediment horizons: from sediment surface to $1 \mathrm{~cm}$ deep, from 1 to $2 \mathrm{~cm}$ deep and from 2 to $3 \mathrm{~cm}$ deep. A ${ }^{15} \mathrm{~N}$ isotope pairing technique was applied for measurement of $\mathrm{N}$-related activities. The principle and procedure for measuring $\mathrm{N}_{2}$ production via anammox were essentially based on a ${ }^{15} \mathrm{~N}$-tracer incubation method reported elsewhere (Thamdrup and Dalsgaard, 2002). However, in this study, we used a simpler method developed previously (Amano et al., 2011; Yoshinaga et al., 2011). Briefly, about two grams of sediment was dispensed into $10 \mathrm{~mL}$ glass serum vials, which were sealed with butyl rubber stoppers and aluminum caps. All these procedures were performed in an anaerobic chamber (Coy Laboratory Products, Grass Lake Charter Township, MI), where $\mathrm{O}_{2}$ concentration was $<1 \mathrm{ppm}$. Headspace in the vials was exchanged with highly pure He gas $(>99.9999 \%)$ by vacuuming and purging. Positive pressure $(50-75 \mathrm{kPa})$ was added to the headspace to prevent unintentional contamination with ambient air during the incubation and gas sampling. The vials containing oxygen-free sediment suspensions were pre-incubated overnight in the dark to elimi- nate the remaining substrates. Four different combinations of ${ }^{15} \mathrm{~N}$ labeled and/or unlabeled substrates were supplemented from anoxic stock solutions to these pre-incubated vials: (1) $0.5 \mathrm{mM}{ }^{15} \mathrm{NH}_{4} \mathrm{Cl}$ ( $\geq 98$ atom $\%{ }^{15} \mathrm{~N}$, Sigma-Aldrich, Inc.); (2) $0.5 \mathrm{mM}{ }^{15} \mathrm{NH}_{4} \mathrm{Cl}$ and $0.5 \mathrm{mM} \mathrm{Na}^{14} \mathrm{NO}_{2}$ (SigmaAldrich, Inc.); (3) $0.5 \mathrm{mM} \mathrm{Na}{ }^{15} \mathrm{NO}_{2}$ (98 atom $\%{ }^{15} \mathrm{~N}$, SigmaAldrich, Inc.); and (4) $0.5 \mathrm{mM} \mathrm{K}^{15} \mathrm{NO}_{3}$ (98 atom $\%{ }^{15} \mathrm{~N}$, Sigma-Aldrich, Inc.). The concentration of the ${ }^{15} \mathrm{~N}$-labeled and unlabeled substrate was chosen as suggested previously (Amano et al., 2007). The vials were incubated under anoxic conditions at in situ temperature. The concentrations of ${ }^{29} \mathrm{~N}_{2}$ and ${ }^{30} \mathrm{~N}_{2}$ gas were determined by gas chromatography-mass spectrometry (GC-MS) analysis at different intervals as described previously (Isobe et al., 2011a, b). In combination with GC inlet and peak integration software, a quadrupole MS system can be used to determine $\mathrm{N}_{2}$ production rates $<10$ nmol N L ${ }^{-1} \mathrm{~d}^{-1}$ (Holtappels et al., 2011). A total of $50 \mu \mathrm{L}$ of headspace gas were collected using a gas-tight syringe (VICI; Baton Rouge, LA, USA), immediately injected into a GC (Agilent 7890A system equipped with a CP-7348 PoraBond Q column) combined with 5975C quadrupole inert MS (Agilent Technologies; Santa Clara, CA, USA). The $m / z=29$ and 30 values were monitored at the same retention time for each measurement. The amounts of ${ }^{29} \mathrm{~N}_{2}$ and ${ }^{30} \mathrm{~N}_{2}$ gas were determined using a standard curve prepared with ${ }^{30} \mathrm{~N}_{2}$ standard gas (>98\% purity; Cambridge Isotope Laboratories; Tewksbury, MA, USA). The potential denitrification and anammox rates were estimated from the production of ${ }^{29} \mathrm{~N}_{2}$ and ${ }^{30} \mathrm{~N}_{2}$ using the equations (provided in Supplement) described previously (Holtappels et al., 2011; Yoshinaga et al., 2011).

All the batch tests were performed in triplicate. Finally, the denitrification and anammox rates were standardized to surface area integrating $3 \mathrm{~cm}$ sediment depth by averaging the rates measured at different horizons and taking into account the sediment bulk density.

\subsection{Atmospheric $\mathrm{N}_{2}$ fixation rates}

We measured $\mathrm{N}_{2}$ fixation by Acetylene Reduction Assay (Capone and Taylor, 1980) in seagrass roots, seagrass shoot epiphytes, vegetated sediment, and adjacent bare sediment. At each sampling time, we carefully collected shoots containing roots and placed them in zip-lock plastic bags. The shoots were immediately transported to the laboratory in a cooler box protected from sunlight. We also collected six cylindrical plastic cores $(40 \mathrm{~cm}$ length and $10 \mathrm{~cm}$ in diameter, three replicate cores per each sediment type) containing at least $15 \mathrm{~cm}$ of undisturbed sediment. The sediment cores were transported immediately to the laboratory. Once in the laboratory the roots were carefully separated from shoots and rinsed with sterilized seawater. Then we placed $10 \mathrm{~g}$ (fresh weight) of healthy roots in a $250 \mathrm{~mL}$ glass bottle. Similarly, we placed one shoot (without roots) in a $500 \mathrm{~mL}$ glass bottle. We added 100 and $250 \mathrm{~mL}$ of fresh seawater collected 
from the same location to the root and shoot samples, respectively, and the bottles were closed with lids fitted with gastight valves. In parallel, the sediment from the cores was extruded carefully using a plunger, and the sediment was cut in four different horizons: from sediment surface to $1 \mathrm{~cm}$ deep, from 1 to $2 \mathrm{~cm}$ deep, from 2 to $3 \mathrm{~cm}$ deep, and from 9 to $10 \mathrm{~cm}$ deep. We added the additional deeper sediment layer (9 to $10 \mathrm{~cm})$, matching the maximum depth at which seagrass roots were detected. For each horizon, $80 \mathrm{~mL}$ of sediment was placed in a $500 \mathrm{~mL}$ glass bottle. Then we added $200 \mathrm{~mL}$ of fresh seawater collected from the same location and the bottles were closed with a lid fitted with a gas-tight valve. Finally, we added acetylene-saturated seawater, prepared according to Wilson et al. (2012), through the gas-tight valve in order to achieve a final acetylene concentration of $4 \mathrm{mM}$ $(10 \mathrm{~mL}$ to roots and $20 \mathrm{~mL}$ to shoots and sediment incubations). The acetylene was added in the form of acetylenesaturated seawater to reduce the acetylene equilibration time and, therefore, avoid potential underestimation of ethylene production rates (Wilson et al., 2012). We ran the root and shoot incubations in triplicate. Similarly, we run the sediment incubation in triplicate for each horizon and sediment type. The roots and sediment slurries were incubated under dark conditions, and the shoots were incubated mimicking the natural photoperiod ( $12 \mathrm{~h}$ light at $200 \mu \mathrm{mol}$ photons $\mathrm{m}^{-2} \mathrm{~s}^{-1}$ : $12 \mathrm{~h}$ dark) at in situ temperature.

We sampled the headspace five times, distributed across the $24 \mathrm{~h}$ incubations. Specifically, we withdrew $3 \mathrm{~mL}$ of air from the headspace with a gas-tight syringe. The headspace air sample was immediately injected into a $3 \mathrm{~mL}$ vacuum vial for further analysis of ethylene concentration on a gas chromatographer equipped with a flame ionization detector and coupled to a mass spectrometer (MS-FID-GC, Agilent 7890) using a GS-CarbonPLOT column $(60 \mathrm{~m} \times 320 \mu \mathrm{m} \times 1.5 \mu \mathrm{m}$, Agilent Technologies, USA). We built a calibration curve using three ethylene standards of known concentration (1.5, 9, and $93 \mathrm{ppm}$ ) and helium as a balance gas, supplied by Abdullah Hashim Industrial Gases \& Equipment Co. Ltd. (Jeddah, Saudi Arabia). We estimated the concentration of dissolved ethylene before equilibrium with the headspace, from the ethylene concentration in the equilibrated air according to Wilson et al. (2012) and applying the solubility coefficient of ethylene extracted from Breitbarth et al. (2004) as a function of temperature and salinity.

We run the following negative controls at each sampling event: (i) roots, shoots, and sediment without addition of acetylene-saturated seawater in order to confirm that ethylene was not naturally produced by our samples, and (ii) seawater collected from the study site and used in the preparation of the incubations with addition of acetylene-saturated seawater in order to measure the $\mathrm{N}_{2}$ fixation due to pelagic diazotrophs. The ethylene production rate measured in the seawater control was subtracted from the ethylene production rates detected in our samples. The net ethylene rates (after subtracting the background seawater rate) were converted into $\mathrm{N}_{2}$ fixation rates by applying the common ratio of $3 \mathrm{~mol}$ of acetylene : 1 mol of $\mathrm{N}_{2}$ (Welsh, 2000).

At the end of the incubation, we dried the roots, shoots, and sediment samples at $60^{\circ} \mathrm{C}$ and recorded the dry weight for further calculations. Moreover, we calculated the sediment organic matter (OM) content of each replicate sediment horizon by loss on ignition (Dean Jr., 1974). Then the sediment $\mathrm{N}_{2}$ fixation rates were standardized to surface area integrated over $3 \mathrm{~cm}$ sediment depth by averaging the rates measured at the first 3 sediment horizons and taking into account the sediment bulk density in order to compare $\mathrm{N}_{2}$ fixation to denitrification and anammox rates. The $\mathrm{N}_{2}$ fixation rates of roots and shoot epiphytes were standardized to surface area taking into account the biomass density.

\subsection{Statistical analysis}

Differences in OM content (our continuous response variable) were tested considering the categorical explanatory variables "sediment type" (2 levels: vegetated and bare sediments) with the non-parametric Wilcoxon test. Furthermore, we analyzed OM content considering also as explanatory variable "sediment horizons" (4 levels: from sediment surface to $1 \mathrm{~cm}$ deep, from 1 to $2 \mathrm{~cm}$ deep, from 2 to $3 \mathrm{~cm}$ deep, and from 9 to $10 \mathrm{~cm}$ deep), and "sampling events" (5 levels: June, August, November, February, and April) by performing a generalized linear model (GLM) and considering their interaction. All the factors were fixed and orthogonal.

Differences in $\mathrm{O}_{2}$ concentration and $\mathrm{H}_{2} \mathrm{~S}$ concentration between vegetated and bare sediments and between light and dark were tested by nonparametric Wilcoxon test.

Differences in denitrification, anammox, and $\mathrm{N}_{2}$ fixation rates per gram of sediment along the sediment horizons between vegetated and bare sediments were tested by Wilcoxon matched-pairs signed rank test. Similarly, we test for differences between denitrification, anammox, and $\mathrm{N}_{2}$ fixation rates by Wilcoxon matched-pairs signed rank test. Moreover, we analyzed the difference in denitrification, anammox, and $\mathrm{N}_{2}$ fixation rates per gram of sediment considering the type of sediment and the sediment OM content as our categorical and continuous explanatory variables, respectively. Since the distribution of denitrification, anammox, and $\mathrm{N}_{2}$ fixation rates per gram of sediment was not normal, we used a GLM to test for differences.

Finally, we analyzed the difference in depth-integrated denitrification, anammox, and $\mathrm{N}_{2}$ fixation rates, our continuous response variables, considering the type of sediment and sampling event as our categorical explanatory variables. We furthermore analyzed the difference in depth-integrated denitrification, anammox, and $\mathrm{N}_{2}$ fixation rates, considering the type of sediment and temperature as our categorical and continuous explanatory variables, respectively. Since the distribution of the depth-integrated denitrification and $\mathrm{N}_{2}$ fixation rates was not normal, we used a GLM to test for differences, while we used a linear model test to analyze the depth- 
Table 1. Annual variation of in situ seawater temperature. Mean seawater temperature values are daily averages of in situ seawater temperature and temperature range indicate daily oscillations (minimum-maximum). Seawater temperature was recorded every $10 \mathrm{~min}$ over $24 \mathrm{~h}$ for each sampling event.

\begin{tabular}{lrr}
\hline $\begin{array}{l}\text { Sampling } \\
\text { time }\end{array}$ & $\begin{array}{r}\text { Mean seawater } \\
\text { temperature }\left({ }^{\circ} \mathrm{C}\right)\end{array}$ & $\begin{array}{r}\text { Seawater temperature } \\
\text { range }\left({ }^{\circ} \mathrm{C}\right)\end{array}$ \\
\hline Jun 2016 & 32.5 & $31.6-33.6$ \\
Aug 2016 & 31.9 & $31.1-32.8$ \\
Nov 2016 & 28.4 & $27.7-29.2$ \\
Feb 2017 & 22.3 & $21.3-22.8$ \\
Apr 2017 & 29.5 & $28.7-30.0$ \\
\hline
\end{tabular}

integrated anammox rates as its distribution was normal. The effect of temperature and sediment type on the net $\mathrm{N}_{2}$ flux was tested by using a linear model. All statistical analyses were performed using JMP (SAS Institute Inc., USA) and PRISM (GraphPad Software Inc., USA) statistical software.

\section{Results}

\subsection{Water and sediment properties}

The in situ daily average seawater temperature ranged from $22.3^{\circ} \mathrm{C}$ in February to $32.5^{\circ} \mathrm{C}$ in June (Table 1), while annual mean salinity was $41.2 \pm 0.4 \mathrm{PSU}$. The OM content was consistently higher (about $40 \%$ higher) in the vegetated sediments compared to the bare sediment (nonparametric Wilcoxon test, $p<0.0001)$, with annual mean $( \pm \mathrm{SEM})$ OM content of $13.5 \pm 0.1$ and $8.5 \pm 0.1 \%$ of sediment dry weight, respectively, and decreased with increasing depth (Fig. 1a). The sediment OM content significantly differed among sediment type, sampling event, and sediment horizon (GLM; sediment type $\times$ sampling event $\times$ sediment horizon $\left.\chi_{12,80}^{2}=28.7 ; p=0.004\right)$. The maximum depth-integrated mean OM content in vegetated sediments $(15 \%$ of sediment dry weight) and bare sediments $(9.5 \%$ of sediment dry weight) was found in November and June, respectively.

Sediment $\mathrm{O}_{2}$ microprofiles significantly differed between vegetated and bare sediments during light and dark measurements (nonparametric Wilcoxon test, $p=0.0002$ and $p<0.0001$, respectively) and between light and dark conditions in both vegetated and bare sediments (nonparametric Wilcoxon test, $p<0.0001$ and $p<0.0001$, respectively). The vegetated and bare sediments were anoxic below the sediment surface but the sediment depth at which anoxic conditions prevailed varied depending on sediment type, light or dark conditions, and the time of the year (Fig. 1b, c). In vegetated sediments, the anoxic conditions appeared at deeper layers than in the bare sediments. Similarly, $\mathrm{O}_{2}$ diffused into deeper sediment layers during light incubations than during dark incubations for both vegetated and bare sediments. On

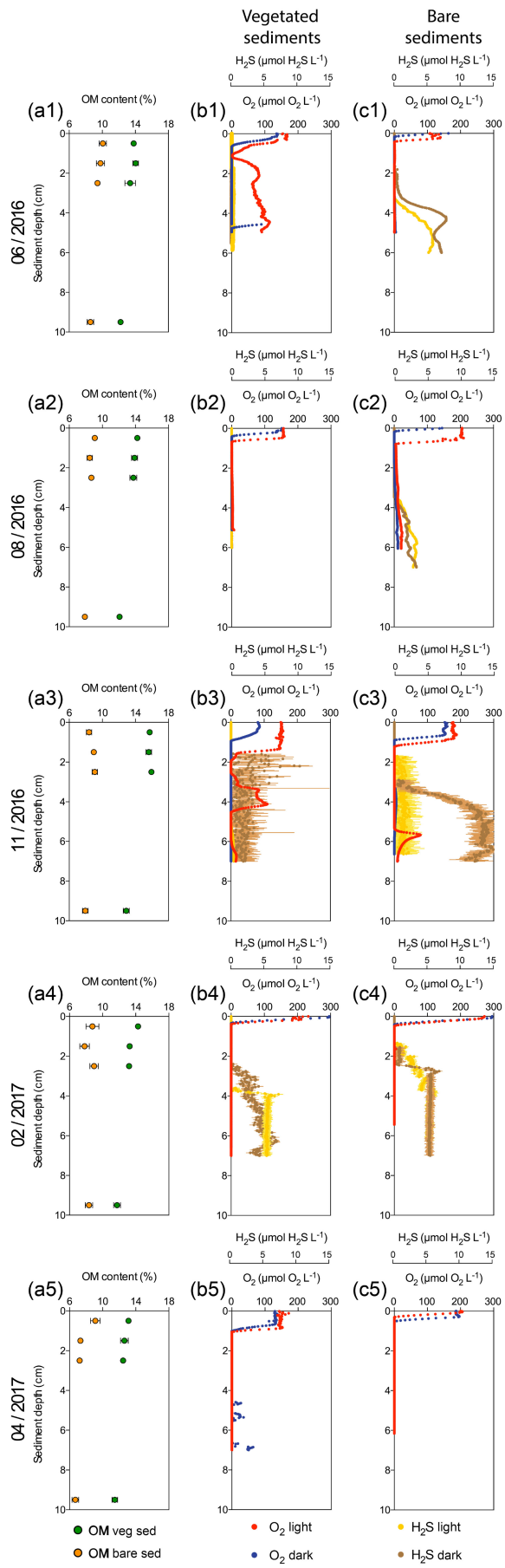

Figure 1. Characterization of Enhalus acoroides seagrass vegetated sediments and adjacent bare sediments at five sampling times throughout the year. (a1-a5) Sediment organic matter content in vegetated (green dots) and bare (orange dots) sediment horizons. (b1-b5) Vegetated sediment $\mathrm{O}_{2}$ microprofiles under light (red) and dark (blue) incubations and $\mathrm{H}_{2} \mathrm{~S}$ microprofiles during light (yellow) and dark (brown) incubations (no data available for $\mathrm{H}_{2} \mathrm{~S}$ profiles on the last sampling). (c1-c5) Bare sediment $\mathrm{O}_{2}$ microprofiles under light (light red) and dark (dark red) incubations and $\mathrm{H}_{2} \mathrm{~S}$ microprofiles under light (yellow) and dark (brown) incubations (no data available for $\mathrm{H}_{2} \mathrm{~S}$ profiles on the last sampling). 
average, the vegetated sediments were anoxic at $1 \pm 0.3$ and $0.7 \pm 0.1 \mathrm{~cm}$ below the surface under light and dark conditions, respectively, while bare sediments were anoxic at $0.6 \pm 0.2$ and $0.4 \pm 0.1 \mathrm{~cm}$ below the surface under light and dark conditions, respectively. In some vegetated sediments under light conditions (Fig. 1b1, b3), the $\mathrm{O}_{2}$ concentration increased again at deep layers, likely indicating $\mathrm{O}_{2}$ release by seagrass roots into the sediment or $\mathrm{O}_{2}$ diffusion through animal burrows.

Sediment $\mathrm{H}_{2} \mathrm{~S}$ microprofiles were highly variable across the year (Fig. $1 b, c$ ). Under light conditions, the $\mathrm{H}_{2} \mathrm{~S}$ concentration in bare sediments (median $=1.28 \mu \mathrm{mol} \mathrm{H}_{2} \mathrm{~S} \mathrm{~L}^{-1}$ ) was significantly higher than in vegetated sediments (median $=0 \mu \mathrm{mol} \mathrm{H}_{2} \mathrm{~S} \mathrm{~L}^{-1}$ ) (nonparametric Wilcoxon test, $p<$ 0.0001). Similarly, under dark conditions, the $\mathrm{H}_{2} \mathrm{~S}$ concentration in bare sediments (median $=1.17 \mu \mathrm{mol} \mathrm{H}_{2} \mathrm{~S} \mathrm{~L}^{-1}$ ) was significantly higher than in vegetated sediments (median $=0.008 \mu \mathrm{mol} \mathrm{H}_{2} \mathrm{~S} \mathrm{~L}^{-1}$ ) (nonparametric Wilcoxon test, $p<0.0001$ ). In vegetated sediments, the $\mathrm{H}_{2} \mathrm{~S}$ concentration was very low $(<0.5 \mu \mathrm{M})$ during the summer months (June and August, Fig. 1b1-b2) and the maximum $\mathrm{H}_{2} \mathrm{~S}$ concentration $(10.4 \mu \mathrm{M})$ was detected in November under dark conditions (Fig. 1b3) at $2.2 \mathrm{~cm}$ below the sediment surface. Bare sediments showed similar $\mathrm{H}_{2} \mathrm{~S}$ profiles under light and dark conditions, except for the dark measurement in November. The maximum $\mathrm{H}_{2} \mathrm{~S}$ concentration in bare sediments $(15.2 \mu \mathrm{M})$ was also detected in November under light conditions, but it was higher than that in vegetated ones and at deeper sediment layers (Fig. 1c3), about $6 \mathrm{~cm}$ below the surface. The redox potential ranged from about 550 to $-450 \mathrm{mV}$ (Fig. S1 in the Supplement) and decreased abruptly with increasing sediment depth.

\subsection{Denitrification, anammox, and $\mathrm{N}_{2}$ fixation rates}

Sediment denitrification rates per gram of sediment were consistently higher in vegetated sediments compared to bare sediments (Wilcoxon matched-pairs signed rank test, $p=0.0015$, Fig. 2a). The highest denitrification rates were detected in summer (June and August, Fig. 2a1a2) for both vegetated and bare sediments. In vegetated sediments, the maximum denitrification rate $(20.52 \pm$ $0.6 \mathrm{nmol} \mathrm{Ng} \mathrm{DW}^{-1} \mathrm{~h}^{-1}$ ) was found in June and was almost twice the maximum rate measured in bare sediments $\left(11.5 \pm 4.2 \mathrm{nmol} \mathrm{Ng} \mathrm{DW}^{-1} \mathrm{~h}^{-1}\right)$, which was found in August. Although the rates varied throughout the year, the maximum denitrification rates took place between 1 and $2 \mathrm{~cm}$ below the surface, with minimum rates detected in the sediment surface. Anammox rates per gram of sediment were consistently lower than denitrification rates (Wilcoxon matched-pairs signed rank test, $p<0.0001$ ) and without significant difference between vegetated and bare sediments (Wilcoxon matched-pairs signed rank test, $p=$ 0.6788 , Fig. $2 b)$. In vegetated sediments, the maximum anammox rate $\left(6.88 \pm 0.5 \mathrm{nmol} \mathrm{N} \mathrm{g} \mathrm{DW}^{-1} \mathrm{~h}^{-1}\right)$ was detected
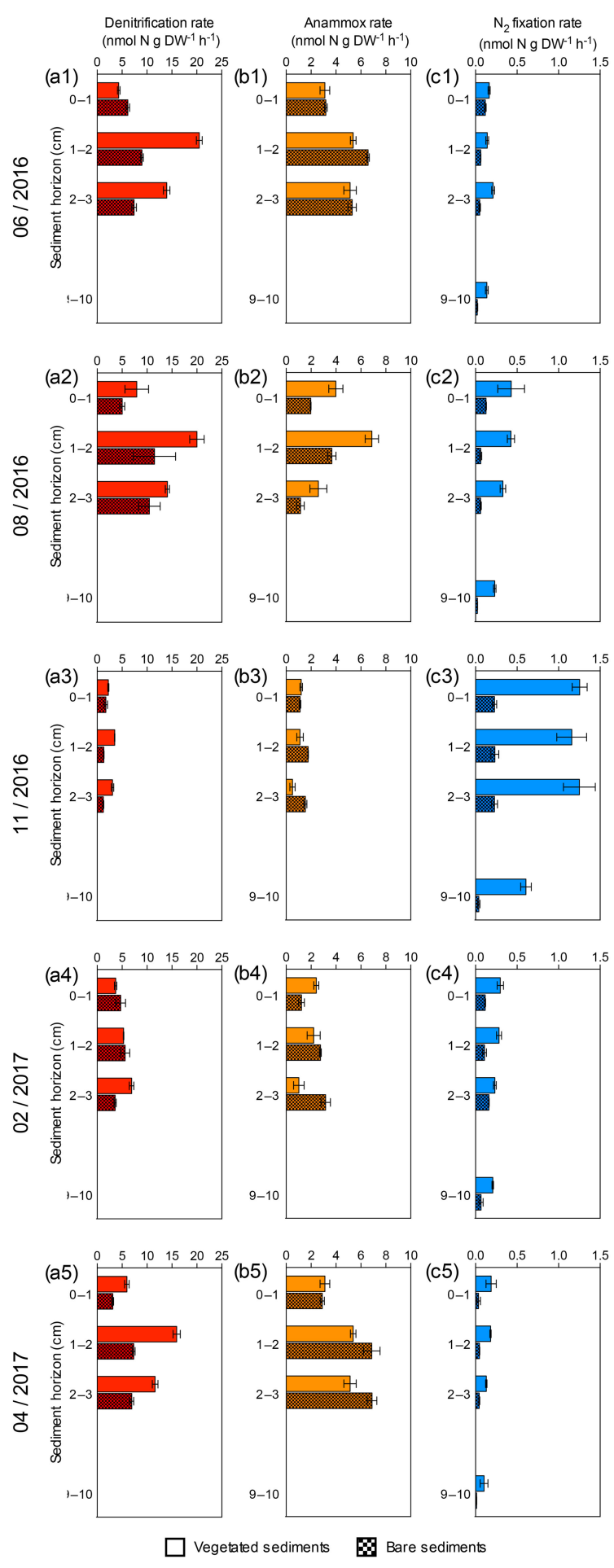

Figure 2. Sediment profiles of denitrification, anammox and $\mathrm{N}_{2}$ fixation rates at five sampling times. (a1-a5) Sediment denitrification rates in vegetated (red) and bare (red square pattern) sediment horizons. (b1-b5) Sediment anammox rates in vegetated (orange) and bare (orange square pattern) sediment horizons. (c1-c5) Sediment $\mathrm{N}_{2}$ fixation rates in vegetated (blue) and bare (blue square pattern) sediment horizons. Error bars indicate SEM. 
in August and was similar to the maximum rate in bare sediments $\left(6.89 \pm 0.4 \mathrm{nmol} \mathrm{N} \mathrm{g} \mathrm{DW}^{-1} \mathrm{~h}^{-1}\right)$, measured in April. The minimum denitrification and anammox rates were measured in November. Sediment $\mathrm{N}_{2}$ fixation rates per gram of sediment (Fig. 2c) were significantly lower than denitrification and anammox rates (Wilcoxon matched-pairs signed rank test, $p<0.0001$ and $p<0.0001$, respectively), with maximum $\mathrm{N}_{2}$ fixation rates $\left(1.25 \pm 0.1 \mathrm{nmol} \mathrm{N} \mathrm{g} \mathrm{DW}^{-1} \mathrm{~h}^{-1}\right)$ detected in November, in contrast to the denitrification and anammox patterns. The $\mathrm{N}_{2}$ fixation rates were significantly higher in vegetated sediments than those rates measured in bare sediments (Wilcoxon matched-pairs signed rank test, $p<0.0001$, Fig. 2c).

Denitrification rates per gram of sediment differed between vegetated and bare sediments at different sediment horizons, however sediment OM content did not have a significant effect (GLM; sediment type $\chi_{1,28}^{2}=5.6, p<0.05$; OM content $\chi_{1,28}^{2}=3.1, p=0.08$ ) (Fig. 3a). The sediment OM content and the type of sediment had a significant effect on anammox rates (GLM; sediment type $\chi_{1,28}^{2}=4.5$, $p<0.05$; OM content $\left.\chi_{1,28}^{2}=5.1, p<0.05\right)$ and $\mathrm{N}_{2}$ fixation rates (GLM; sediment type $\times$ OM content $\chi_{1,36}^{2}=14.2$, $p<0.001)$. Anammox rates decreased with increasing $\mathrm{OM}$ content in vegetated sediments $(Y=-1.04 X+17.8, p<$ 0.05 , Fig. 3b), while $\mathrm{N}_{2}$ fixation rates increased with increasing $\mathrm{OM}$ content in vegetated sediment $(Y=0.24 X-2.9$, $p<0.0001$, Fig. 3c).

The differences in denitrification rates between vegetated and bare sediment rates became smaller when depthintegrated $(0-3 \mathrm{~cm})$ rates were compared (Fig. 4a), largely due to the higher (1.5-fold) bulk density in bare sediments compared to vegetated sediments. Depth-integrated denitrification rates significantly differed among sampling events but not between vegetated and bare sediments (GLM; sampling event $\chi_{4,24}^{2}=70.6, p<0.0001$; sediment type $\chi_{1,24}^{2}=3.1, p=0.08$ ), with minimum rates observed in November in both sediment types. Depth-integrated anammox rates (Fig. 4b) significantly differed among sampling events and between vegetated and bare sediments $(\mathrm{lm}$, sampling event $\times$ sediment type; $F_{4,29}=30.05, p<0.0001$ ). Minimum depth-integrated anammox rates were detected in November in both sediment types; however, rates were consistently higher in bare sediments compared to vegetated sediments throughout the year. Similarly, depth-integrated $\mathrm{N}_{2}$ fixation rates (Fig. 4c) significantly differed among sampling events and between vegetated and bare sediments (GLM; sampling event $\times$ sediment type $\chi_{4,20}^{2}=73.31, p<$ 0.0001 ), with consistently higher rates in vegetated sediments. Maximum depth-integrated $\mathrm{N}_{2}$ fixation rates were observed in November in both types of sediments.
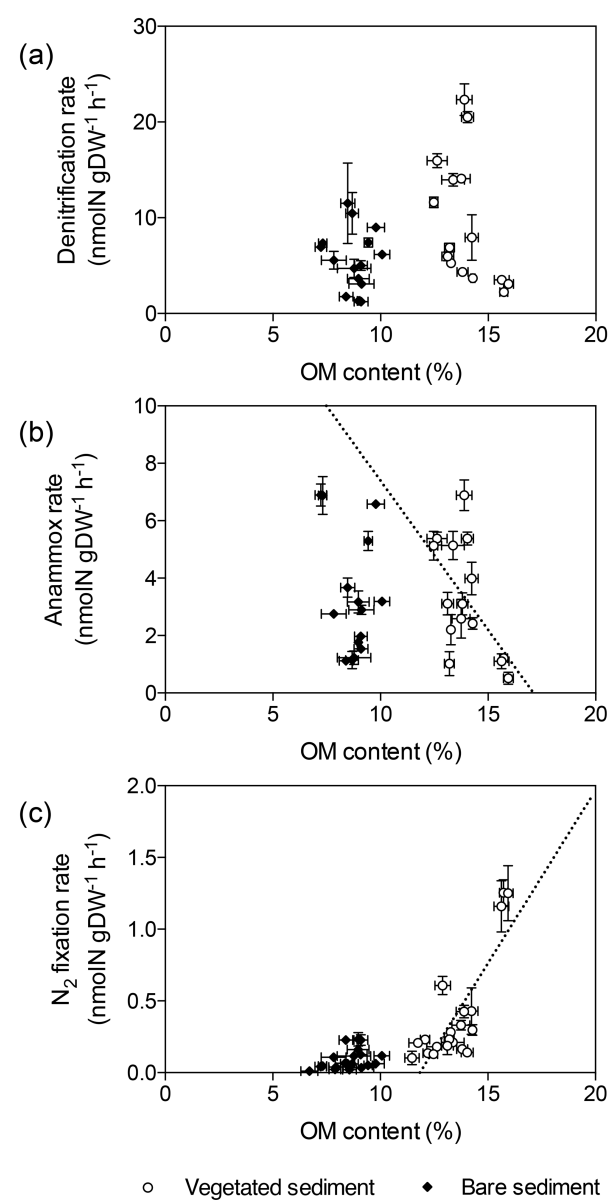

Figure 3. Relation of denitrification, anammox, and $\mathrm{N}_{2}$ fixation rates with sediment $\mathrm{OM}$ content. (a) Denitrification rates in vegetated sediments (white dots) and bare sediments (black diamonds). (b) Anammox rates in vegetated (white dots) and bare (black diamonds) sediments, showing the linear decrease of anammox rates in vegetated sediments with increasing $\mathrm{OM}$ content (dotted line) (c) $\mathrm{N}_{2}$ fixation rates in vegetated sediments (white dots) and bare sediments (black diamonds), showing the linear increase of $\mathrm{N}_{2}$ fixation rates in vegetated sediments with increasing OM content (dotted line). Error bars indicate SEM.

\subsection{Effect of temperature on denitrification, anammox, and $\mathbf{N}_{2}$ fixation rates}

Temperature had a significant effect on depth-integrated denitrification rates regardless of the type of sediment $\left(\mathrm{GLM}\right.$; temperature $\chi_{1,27}^{2}=16.67, p<0.0001$; sediment type $\left.\chi_{1,27}^{2}=0.53, p=0.46\right)$. Depth-integrated denitrification rates increased linearly with temperature $(Y=3.569 X-$ 65, Fig. 5a). Temperature and sediment type had a significant effect on depth-integrated anammox rates $(\mathrm{lm}$; temperature $F_{1,29}=14.8, p=0.0007$; sediment type, $F_{1,29}=$ 7.7, $p=0.01)$, with rates increasing linearly in vegetated $(Y=1.3 X-20.36)$ and bare $(Y=1.3 X-16.94)$ sediments (Fig. 5b). However, depth-integrated $\mathrm{N}_{2}$ fixation rates did 
(a)

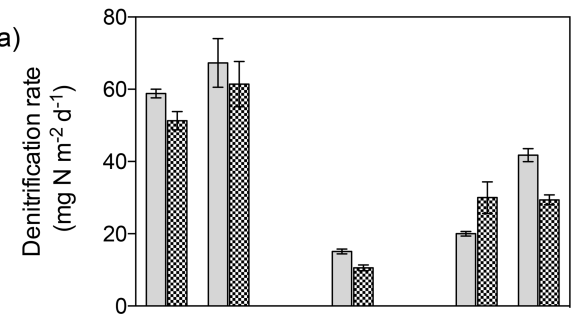

(b)

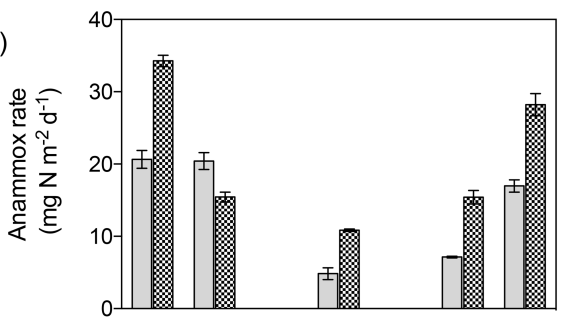

(c)

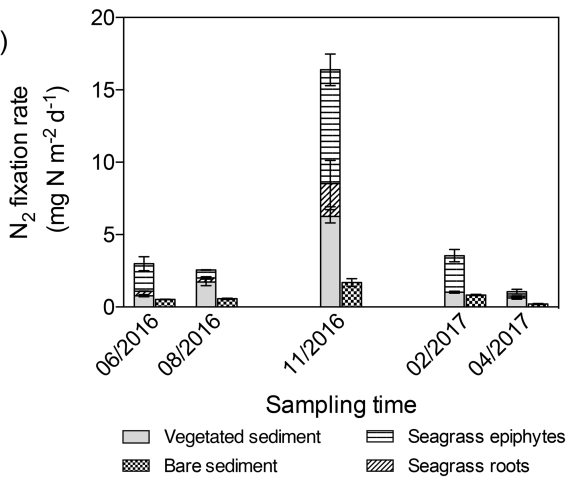

Figure 4. Area integrated sediment rates throughout the year. (a) Denitrification rates in vegetated (gray) and bare (square pattern) sediments. (b) Anammox rates in vegetated (gray) and bare (square pattern) sediments. (c) $\mathrm{N}_{2}$ fixation rates in vegetated (gray) and bare (square pattern) sediments, in seagrass roots (angled stripes), and epiphytes (horizontal stripes). Error bars indicate SEM.

not increase linearly with temperature and the differences in rates were explained by sediment type (GLM; sediment type $\chi_{1,27}^{2}=4.93, p=0.03$ ). Sediment $\mathrm{N}_{2}$ fixation rates in vegetated and bare sediments showed a different thermal response than denitrification and anammox processes, with maximum rates reported at $28.5^{\circ} \mathrm{C}$ and decreasing rates at either lower and higher temperatures (Fig. 5c). $\mathrm{N}_{2}$ fixation rates followed a second-degree polynomial curve $\left(Y=16.94-0.45 X-0.13 X^{2}, r^{2}=0.40, p<0.05\right)$ in vegetated sediments. $\mathrm{N}_{2}$ fixation rates in seagrass roots and epiphytes showed the same annual pattern that the rates reported for the rhizosphere. The maximum rates in seagrass roots $\left(21.9 \pm 210.7 \mu \mathrm{g} \mathrm{N} \mathrm{DW}^{-1} \mathrm{~d}^{-1}\right)$ and epiphytes $\left(10.4 \pm 1.5 \mu \mathrm{g} \mathrm{N} \mathrm{g} \mathrm{DW}{ }^{-1} \mathrm{~d}^{-1}\right)$ were also recorded in November when in situ seawater temperature was $28.5^{\circ} \mathrm{C}$ (Fig. 5c).

\subsection{Net $\mathrm{N}_{2}$ fluxes}

The net $\mathrm{N}_{2}$ fluxes ranged from $3.6 \pm 0.8$ and $19.73 \pm$ $0.9 \mathrm{mg} \mathrm{N} \mathrm{m}^{-2} \mathrm{~d}^{-1}$ in November, to $85.1 \pm 3.7$ and $85.1 \pm$

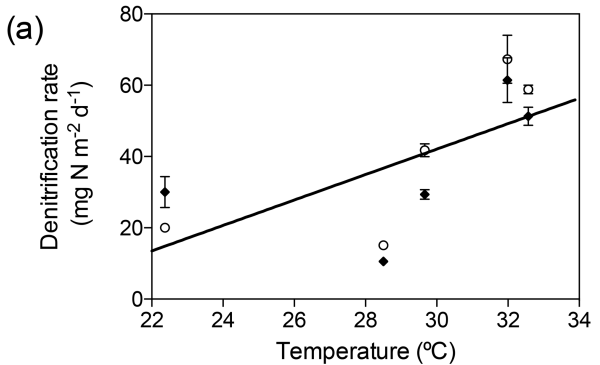

(b)

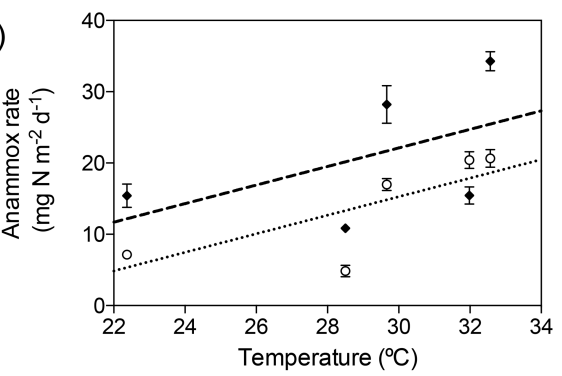

(c)

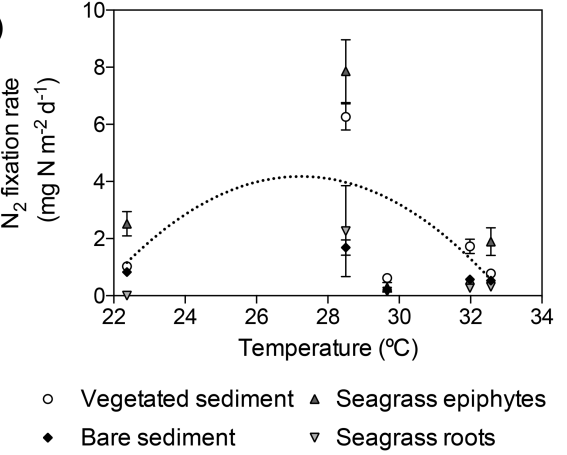

Figure 5. Relation of denitrification, anammox, and $\mathrm{N}_{2}$ fixation rates to in situ seawater temperature. (a) Linear increase of denitrification rates (solid line) with temperature, showing denitrification rates in vegetated sediments (white dots) and bare sediments (black diamonds). (b) Linear increase of anammox rates in vegetated (dotted line and white dots) and bare (dashed line and black diamonds) sediments. (c) Thermal response of $\mathrm{N}_{2}$ fixation rates in vegetated sediments (white dots), bare sediments (black diamonds), seagrass epiphytes (triangles) and roots (upside down triangles), showing the fitted second-degree polynomial curve in vegetated sediment (dotted line). Error bars indicate SEM.

$2.6 \mathrm{mg} \mathrm{N} \mathrm{m}^{-2} \mathrm{~d}^{-1}$ in summer months for the seagrass meadow and bare sediments, respectively (Fig. 6). The net $\mathrm{N}_{2}$ flux significantly differed among sampling events but not between sediment type $\left(\mathrm{lm}\right.$; sampling event $F_{4,9}=24.76$, $p=0.004$; sediment type, $\left.F_{1,9}=1.83, p=0.25\right)$. Net $\mathrm{N}_{2}$ flux increased linearly with temperature $(Y=4.99 X-91.86$, $r^{2}=0.43, p<0.05$, Fig. 7).

\section{Discussion}

The sediment organic matter content in the Red Sea lagoon system studied here was extremely high, especially in the 


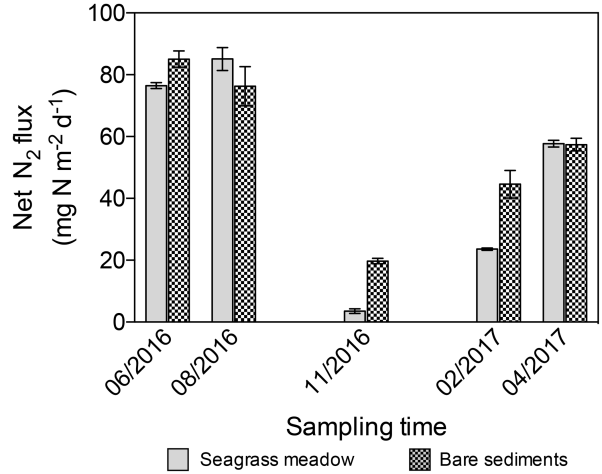

Figure 6. Net $\mathrm{N}_{2}$ flux in seagrass meadow (gray) and bare sediment (square pattern gray) throughout the year, considering sediment denitrification and anammox as $\mathrm{N}$ losses and sediment and seagrass roots and epiphytes $\mathrm{N}_{2}$ fixation as new $\mathrm{N}$ inputs. Error bars indicate SEM.

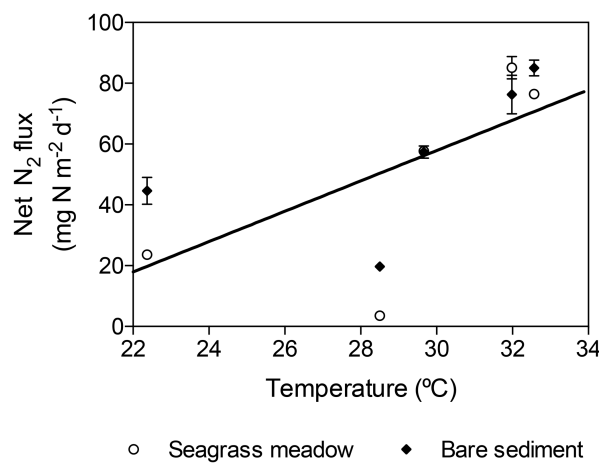

Figure 7. Linear increase (solid line) of net $\mathrm{N}_{2}$ fluxes in vegetated (white dots) and bare (black diamonds) sediments. Error bars indicate SEM.

vegetated sediments $($ mean $=13.5 \%)$, compared to the values reported for other seagrass sediments $($ mean $=4.1 \%$, Kennedy et al., 2010). The higher sediment organic matter content in vegetated sediments, compared to bare sediments, corroborates the evidence that seagrasses accumulate and store large amounts of organic carbon in their sediments (Duarte et al., 2005). In addition, seagrasses modified the physicochemical conditions of the sediment (Enriquez et al., 2001), as reflected in higher $\mathrm{O}_{2}$ and lower sulfide sediment concentrations than those in the adjacent bare sediment. Moreover, $\mathrm{O}_{2}$ profiles showed higher variability in vegetated sediments. This can be directly related to bioturbation (Kristensen et al., 2012) and to the radial oxygen loss by roots leading to oxic layers at depth (Pedersen et al., 1998), enhancing the complexity and heterogeneity of seagrass sediments.

The denitrification rate in E. acoroides sediments reported here (annual mean $=34.9 \pm 10.3 \mathrm{mg} \mathrm{N} \mathrm{m}^{-2} \mathrm{~d}^{-1}$ ) is a 6-fold increase over the rate reported for a restored Zostera marina meadow in Virginia using an in situ push-pull incubation method (Aoki and McGlathery, 2017), a 1.3 to 2.5 -fold increase over the rate previously reported for tropical meadows dominated by $E$. acoroides on slurries from the top $5 \mathrm{~cm}$ sediment (Alongi et al., 2008), comparable to the rates reported for temperate seagrasses (Eyre et al., 2016), and 8-fold lower than the rates reported for sub-tropical estuarine seagrasses (Eyre et al., 2011a) using in situ benthic chambers. However, the use of the ${ }^{15} \mathrm{~N}$ isotope pairing technique on sediment slurries could have underestimated denitrification rates reported here. Measuring $\mathrm{N}_{2}$ fluxes on intact sediment cores has been proved to better account for coupled nitrification and denitrification than the ${ }^{15} \mathrm{~N}$ isotope pairing technique (van Luijn et al., 1996). In addition, sediment slurries disturb the sediment structure and redox gradient, and, therefore, might prevent the coupled nitrification and denitrification in the transition layers from oxic to anoxic conditions (Eyre et al., 2002; Herbert, 1999). Since the coupled nitrification and denitrification has been reported to be important in continental shelf and coastal sediments (Herbert, 1999; Gardner and McCarthy, 2009; Christensen et al., 1987); the denitrification rates in this coastal lagoon could be higher than actual reported values.

Overall, the observed denitrification rates were higher in vegetated sediments than bare sediments when expressed per gram of dried sediment. However, we did not find differences between depth-integrated denitrification rates in vegetated and bare sediments (annual mean $=34.9 \pm 10.3$ and $31.6 \pm 8.9 \mathrm{mg} \mathrm{N} \mathrm{m}^{-2} \mathrm{~d}^{-1}$, respectively) contrary to previous findings (Eyre et al., 2011b).

The potential sediment anammox rates reported here, ranging from 0.5 to $6.9 \mathrm{nmol} \mathrm{Ng} \mathrm{DW}^{-1} \mathrm{~h}^{-1}$, are comparable to potential anammox rates reported elsewhere (i.e., from 0 to $8 \mathrm{nmol} \mathrm{N} \mathrm{cm}^{-3} \mathrm{~h}^{-1}$ in subtropical mangrove sediments (Meyer et al., 2005); from $<0.5$ to $7.6 \mathrm{nmol} \mathrm{N} \mathrm{g} \mathrm{DW}^{-1} \mathrm{~h}^{-1}$ in marine sediments from a fjord in Sweden (Brandsma et al., 2011) and from 0 to $3 \mathrm{nmol} \mathrm{N} \mathrm{cm}{ }^{-3} \mathrm{~h}^{-1}$ in sandy sediments in the southern North Sea; Bale et al., 2014). However, the potential sediment anammox rates detected here (annual mean depth-integrated anammox rates $=12.4 \pm 3.4$ and $19.8 \pm 4.4 \mathrm{mg} \mathrm{N} \mathrm{m}^{-2} \mathrm{~d}^{-1}$ in vegetated and bare sediments, respectively) are higher than the only estimate available, to the best of our knowledge, for a seagrass ecosystem $\left(0.06 \mathrm{mg} \mathrm{N} \mathrm{m}^{-2} \mathrm{~d}^{-1}\right.$ in bare sediment adjacent to a subtropical seagrass meadow in Australia on intact cores; Salk et al., 2017). The contribution of anammox to the total loss of $\mathrm{N}$ reported here $(27 \%$ and $38 \%$ in vegetated and bare sediments, respectively, Fig. S2) is smaller than the contribution reported by Salk et al. (2017), with anammox accounting for $64 \%$ to $86 \%$ of the total $\mathrm{N}$ loss, but still within the range of anammox-supported $\mathrm{N}$ losses reported for other marine sediments (Devol, 2015; Bale et al., 2014).

The maximum $\mathrm{N}_{2}$ fixation rates reported for $E$. acoroides sediments here $\left(6.3 \pm 0.5 \mathrm{mg} \mathrm{N} \mathrm{m}^{-2} \mathrm{~d}^{-1}\right)$ are lower than the previously reported maximum $\mathrm{N}_{2}$ fixation rates in sediments of a tropical mixed meadow dominated by $E$. acoroides 
(19.4 $\pm 3.2 \mathrm{mg} \mathrm{N} \mathrm{m}^{-2} \mathrm{~d}^{-1}$, Alongi et al., 2008). Similarly, Moriarty and O'Donohue (1993) reported higher $\mathrm{N}_{2}$ fixation rates for a mixed meadow dominated by $E$. acoroides $\left(25 \pm 2.6 \mathrm{mg} \mathrm{N} \mathrm{m}^{-2} \mathrm{~d}^{-1}\right)$ than those reported here during the same time of the year $\left(16.4 \pm 0.4 \mathrm{mg} \mathrm{N} \mathrm{m}^{-2} \mathrm{~d}^{-1}\right)$, although with a smaller contribution from leaf epiphytes $(4.2 \pm$ $0.1 \mathrm{mg} \mathrm{N} \mathrm{m}^{-2} \mathrm{~d}^{-1}$ ) compared with our $\mathrm{N}_{2}$ fixation rates from epiphytes $\left(7.9 \pm 1.1 \mathrm{mg} \mathrm{N} \mathrm{m}^{-2} \mathrm{~d}^{-1}\right)$. The $\mathrm{N}_{2}$ fixation rates supported by roots are in agreement with previous findings of $\mathrm{N}_{2}$-fixing bacteria in association with seagrass roots (Garcias-Bonet et al., 2012, 2016). Moreover, the $\mathrm{N}_{2}$ fixation rates previously reported for surface-sterilized $E$. acoroides roots $\left(0.13 \mathrm{mg} \mathrm{N} \mathrm{m}^{-2} \mathrm{~d}^{-1}\right.$; Raja et al., 2012) are 17-fold lower than the rates reported here $\left(2.3 \pm 1.5 \mathrm{mg} \mathrm{N} \mathrm{m}^{-2} \mathrm{~d}^{-1}\right)$ for the same seawater temperature $\left(29^{\circ} \mathrm{C}\right)$, pointing out the role of bacteria inhabiting the rhizoplane of E. acoroides roots in nutrient supply. Despite the common use of the ARA to measure $\mathrm{N}_{2}$ fixation in natural communities, such as open ocean waters (i.e., Falcón et al., 2004) and vegetated coastal sediments (i.e., Eyre et al., 2011a), including seagrass sediments (see references in Welsh, 2000) and seagrass tissues (Nielsen et al., 2001; Raja et al., 2012), it has some methodological limitations that need to be considered. Acetylene is known to induce changes in the biogeochemistry and the microbial community composition in marine sediments, especially affecting sulfur- and sulfate-reducing bacterial groups (Fulweiler et al., 2015). However, the effect of acetylene is species specific, and, therefore, the $\mathrm{N}_{2}$ fixation rates reported here might be either under- or over-estimated and need to be carefully interpreted.

The highest $\mathrm{N}_{2}$ fixation rates in vegetated and bare sediments coincided with the highest sediment sulfide concentrations (10.4 and $15.2 \mu \mathrm{mol} \mathrm{H} \mathrm{S} \mathrm{L} \mathrm{L}^{-1}$ in vegetated and bare sediments, respectively), suggesting a contribution of sulfate-reducing bacteria to the pool of $\mathrm{N}_{2}$-fixing bacteria, as reported in other seagrass rhizospheres (Welsh et al., 1996). Although sulfide has detrimental effects on seagrasses (Garcias-Bonet et al., 2008), the sulfide concentrations in the vegetated sediments were generally below the threshold limit of $10 \mu \mathrm{mol} \mathrm{H}_{2} \mathrm{~S} \mathrm{~L}^{-1}$ for seagrass decline (Calleja et al., 2007).

The contrasting annual patterns in denitrification and anammox compared to those of $\mathrm{N}_{2}$ fixation, with the highest rates of denitrification and anammox in summer and spring while maximum $\mathrm{N}_{2}$ fixation in autumn, suggest differential specific thermal responses. The linear increase of denitrification and anammox with temperature found here was already described for net sediment $\mathrm{N}_{2}$ fluxes in estuaries (Nowicki, 1994). Similarly, the thermal response of $\mathrm{N}_{2}$ fixation found here, with maximum rates at intermediate temperatures $\left(29^{\circ} \mathrm{C}\right)$ and a decrease in rates at lower and higher temperatures, is in agreement with the notable decrease in $\mathrm{N}_{2}$ fixation rates at 33 and $35^{\circ} \mathrm{C}$ reported for Mediterranean macrophytes (Garcias-Bonet et al., 2018) and cyanobacteria in soil crusts (Zhou et al., 2016), respectively. Moreover, these different annual patterns could be partially explained by changes in sediment OM. The sediment microbial activity is modulated, as well, by the quantity and quality of the OM. For instance, decomposition and remineralization rates of OM depends on its lability (Herbert, 1999) which is indicated by the $\mathrm{C}: \mathrm{N}: \mathrm{P}$ ratio that differs among sources (Enríquez et al., 1993). OM from phytoplankton decomposes faster than $\mathrm{OM}$ from seagrasses, due to their higher $\mathrm{N}$ content and therefore lower $\mathrm{C}: \mathrm{N}: \mathrm{P}$ ratios. Eyre et al. (2013) demonstrated that the source of the $\mathrm{OM}$, and therefore, its $\mathrm{C}: \mathrm{N}$ ratio controls denitrification rates in coastal sediments. Tibbles et al. (1994) showed an increase in sediment $\mathrm{N}_{2}$ fixation following the addition of complex plant polysaccharides and Fulweiler et al. (2013) argued that an increase in the $\mathrm{C}: \mathrm{N}$ ratio of $\mathrm{OM}$ was responsible for the decrease in denitrification and the increase in $\mathrm{N}_{2}$ fixation, in agreement with the effect of OM reported here.

The net $\mathrm{N}_{2}$ fluxes in the Red Sea lagoon ecosystem indicates this ecosystem supports a net loss of reactive $\mathrm{N}$ as $\mathrm{N}_{2}$ gas throughout the year, as sediment denitrification and anammox consistently exceeded $\mathrm{N}_{2}$ fixation in sediment and seagrass tissues. Alongi et al. (2008) also reported higher denitrification than $\mathrm{N}_{2}$ fixation rates in an E. acoroides meadow. Integrating the average seasonal rates, we estimate the annual $\mathrm{N}$ loss in $14.9 \mathrm{~g} \mathrm{~N} \mathrm{~m}^{-2} \mathrm{yr}^{-1}$ in the seagrass meadow and $18.2 \mathrm{~g} \mathrm{~N} \mathrm{~m}^{-2} \mathrm{yr}^{-1}$ in bare sediments. Despite the lack of rivers discharging into the Red Sea, the occasional heavy rains, groundwater discharge, and atmospheric deposition might lead to high reactive $\mathrm{N}$ loads reaching coastal systems (Voss et al., 2013). Therefore, the high denitrification and anammox rates in this coastal lagoon provide a mechanism adding resistance to excess $\mathrm{N}$ inputs (Zarnoch et al., 2017; Galloway et al., 2003), which might lead to permanent seagrass losses due to hypoxia after algal blooms produced by severe eutrophication (Herbert, 1999; Duarte, 1995). However, dissimilatory nitrate reduction to ammonium (DNRA) competes with denitrification by reducing nitrate availability. In a shallow estuary, DNRA was identified as an important nitrate loss pathway, with rates comparable to denitrification rates (An and Gardner, 2002); and in a restored Zostera marina meadow, DNRA accounted for $45 \%$ of sediment nitrate reduction (Aoki and McGlathery, 2017). Therefore, the net $\mathrm{N}$ loss reported here could be lower due to a potential limitation of denitrification.

Nevertheless, $\mathrm{N}_{2}$ fixation plays an important role in supporting seagrass meadows in the Red Sea, as the maximum $\mathrm{N}_{2}$ fixation rate reported here could contribute from $7 \%$ to $36.4 \%$ of the $\mathrm{N}$ requirements to support $E$. acoroides growth, calculated using previous estimates of biomass productivity (Alongi et al., 2008; Pedersen et al., 2016) and measured $\mathrm{N}$ content of leaf tissues in this central Red Sea lagoon (Almahasheer et al., 2017). Furthermore, the $\mathrm{N}$ isotopic composition reported for E. acoroides tissues in this location $\left(\delta^{15} \mathrm{~N}_{\text {leaves }}=0.17 \%\right.$ and $\delta^{15} \mathrm{~N}_{\text {rhizomes }}=-1.56 \%$; 
Almahasheer et al., 2017), provides evidence for the atmospheric origin of the assimilated $\mathrm{N}$.

The differential apparent thermal response of denitrification and anammox, which increased with increasing temperature, and $\mathrm{N}_{2}$ fixation, which showed a maximum at about $28^{\circ} \mathrm{C}$, leads to an increase in the net $\mathrm{N}_{2}$ flux with temperature (Fig. 6). This has important implications in a context of the rapid warming of the Red Sea (Chaidez et al., 2017). In particular, a further increase in temperature, with maximum temperatures in excess of $33^{\circ} \mathrm{C}$ at present (Chaidez et al., 2017), might lead to a further imbalance in $\mathrm{N}$ cycling in tropical seagrass ecosystems, similar to that predicted for soil crusts (Zhou et al., 2016). Therefore, the forecasted warming might have an important impact on $\mathrm{N}$ availability and thus on seagrass productivity and their capacity to mitigate climate change.

\section{Conclusion}

The studied coastal lagoon ecosystem supported a net loss of reactive $\mathrm{N}$ as $\mathrm{N}_{2}$, with anammox accounting for about one-third of $\mathrm{N}_{2}$ production. However, $\mathrm{N}_{2}$ fixation supported part of seagrass growth. The results presented suggest that, as a consequence of the differential thermal responses of processes supporting losses and gains of reactive $\mathrm{N}$, future warming can enhance the role of seagrass meadows as sites of reactive $\mathrm{N}$ loss in the already warm Red Sea.

Data availability. Underlying data are provided in the Supplement.

Supplement. The supplement related to this article is available online at: https://doi.org/10.5194/bg-15-7333-2018-supplement.

Author contributions. NGB and CMD designed the study. NGB and $\mathrm{MF}$ performed the fieldwork. NGB performed the $\mathrm{N}_{2}$ fixation measurements. MF performed the sediment microprofiles. MA and DRS performed the denitrification and anammox activity measurements. NGB, MF and CMD interpreted the results. NGB wrote the first draft of the paper. All authors contributed substantially to the final paper.

Competing interests. The authors declare that they have no conflict of interest.

Acknowledgements. This research was funded by King Abdullah University of Science and Technology through baseline funding to Carlos M. Duarte, Daniele Daffonchio, and Pascal E. Saikaly. We thank Mongi Ennasri for his support in sample analysis.

Edited by: S. Wajih A. Naqvi

Reviewed by: three anonymous referees

\section{References}

Almahasheer, H., Serrano, O., Duarte, C. M., Arias-Ortiz, A., Masque, P., and Irigoien, X.: Low Carbon sink capacity of Red Sea mangroves, Sci. Rep.-UK, 7, 9700, https://doi.org/10.1038/s41598-017-10424-9, 2017.

Alongi, D. M., Trott, L. A., Undu, M. C., and Tirendi, F.: Benthic microbial metabolism in seagrass meadows along a carbonate gradient in Sulawesi, Indonesia, Aquat. Microb. Ecol., 51, 141152, https://doi.org/10.3354/ame01191, 2008.

Amano, T., Yoshinaga, I., Okada, K., Yamagishi, T., Ueda, S., Obuchi, A., Sako, Y., and Suwa, Y.: Detection of anammox activity and diversity of anammox bacteria-related 16S rRNA genes in coastal marine sediment in Japan, Microbes Environ., 22, 232 242, 2007.

Amano, T., Yoshinaga, I., Yamagishi, T., Van Thuoc, C., Ueda, S., Kato, K., Sako, Y., and Suwa, Y.: Contribution of anammox bacteria to benthic nitrogen cycling in a mangrove forest and shrimp ponds, Haiphong, Vietnam, Microbes Environ., 26, 1-6, 2011.

An, S. and Gardner, W. S.: Dissimilatory nitrate reduction to ammonium (DNRA) as a nitrogen link, versus denitrification as a sink in a shallow estuary (Laguna Madre/Baffin Bay, Texas), Mar. Ecol.-Prog. Ser., 237, 41-50, 2002.

Aoki, L. R. and McGlathery, K. J.: Push-pull incubation method reveals the importance of denitrification and dissimilatory nitrate reduction to ammonium in seagrass root zone, Limnol. Oceanogr.-Meth., 15, 766-781, 2017.

Bale, N. J., Villanueva, L., Fan, H., Stal, L. J., Hopmans, E. C., Schouten, S., and Sinninghe Damsté, J. S.: Occurrence and activity of anammox bacteria in surface sediments of the southern North Sea, FEMS Microbiol. Ecol., 89, 99-110, 2014.

Brandsma, J., van de Vossenberg, J., Risgaard-Petersen, N., Schmid, M. C., Engström, P., Eurenius, K., Hulth, S., Jaeschke, A., Abbas, B., and Hopmans, E. C.: A multi-proxy study of anaerobic ammonium oxidation in marine sediments of the Gullmar Fjord, Sweden, Env. Microbiol. Rep., 3, 360-366, 2011.

Breitbarth, E., Mills, M. M., Friedrichs, G., and LaRoche, J.: The Bunsen gas solubility coefficient of ethylene as a function of temperature and salinity and its importance for nitrogen fixation assays, Limnol. Oceanogr.-Meth., 2, 282-288, 2004.

Calleja, M., Marba, N., and Duarte, C. M.: The relationship between seagrass (Posidonia oceanica) decline and porewater sulfide pools in carbonate sediments, Estuar. Coast. Shelf S., 73, 583-588, 2007.

Capone, D. G. and Taylor, B. F.: $\mathrm{N}_{2}$ FIXATION IN THE RHIZOSPHERE OF THALASSIA-TESTUDINUM, Can. J. Microbiol., 26, 998-1005, 1980.

Chaidez, V., Dreano, D., Agusti, S., Duarte, C. M., and Hoteit, I.: Decadal trends in Red Sea maximum surface temperature, Sci. Rep.-UK, 7, 8144, https://doi.org/10.1038/s41598-017-08146-z, 2017.

Christensen, J. P., Murray, J. W., Devol, A. H., and Codispoti, L. A.: Denitrification in continental shelf sediments has major impact on the oceanic nitrogen budget, Global Biogeochem. Cy., 1, 97116, 1987.

Dalsgaard, T., Thamdrup, B., and Canfield, D. E.: Anaerobic ammonium oxidation (anammox) in the marine environment, Res. Microbiol., 156, 457-464, https://doi.org/10.1016/j.resmic.2005.01.011, 2005. 
Dean Jr., W. E.: Determination of carbonate and organic matter in calcareous sediments and sedimentary rocks by loss on ignition: comparison with other methods, J. Sediment. Res., 44, 242-248, https://doi.org/10.1306/74D729D2-2B2111D7-8648000102C1865D, 1974.

Devol, A. H.: Denitrification, anammox, and $\mathrm{N}_{2}$ production in marine sediments, Annu. Rev. Mar. Sci., 7, 403-423, 2015.

Duarte, C. M.: Submerged aquatic vegetation in relation to different nutrient regimes, Ophelia, 41, 87-112, 1995.

Duarte, C. M., Middelburg, J. J., and Caraco, N.: Major role of marine vegetation on the oceanic carbon cycle, Biogeosciences, 2, 1-8, https://doi.org/10.5194/bg-2-1-2005, 2005.

Enríquez, S., Duarte, C. M., and Sand-Jensen, K.: Patterns in decomposition rates among photosynthetic organisms: the importance of detritus $\mathrm{C}: \mathrm{N}: \mathrm{P}$ content, Oecologia, 94, 457-471, 1993.

Enriquez, S., Marba, N., Duarte, C. M., van Tussenbroek, B. I., and Reyes-Zavala, G.: Effects of seagrass Thalassia testudinum on sediment redox, Mar. Ecol.-Prog. Ser., 219, 149-158, 2001.

Eyre, B. D., Rysgaard, S., Dalsgaard, T., and Christensen, P. B.: Comparison of isotope pairing and $\mathrm{N}_{2}$ : Ar methods for measuring sediment denitrification-assumption, modifications, and implications, Estuaries, 25, 1077-1087, 2002.

Eyre, B. D., Ferguson, A. J. P., Webb, A., Maher, D., and Oakes, J. M.: Denitrification, N-fixation and nitrogen and phosphorus fluxes in different benthic habitats and their contribution to the nitrogen and phosphorus budgets of a shallow oligotrophic sub-tropical coastal system (southern Moreton Bay, Australia), Biogeochemistry, 102, 111-133, https://doi.org/10.1007/s10533010-9425-6, 2011a.

Eyre, B. D., Maher, D., Oakes, J. M., Erler, D. V., and Glasby, T. M.: Differences in benthic metabolism, nutrient fluxes, and denitrification in Caulerpa taxifolia communities compared to uninvaded bare sediment and seagrass (Zostera capricorni) habitats, Limnol. Oceanogr., 56, 1737-1750, https://doi.org/10.4319/lo.2011.56.5.1737, 2011b.

Eyre, B. D., Maher, D. T., and Squire, P.: Quantity and quality of organic matter (detritus) drives N-2 effluxes (net denitrification) across seasons, benthic habitats, and estuaries, Glob. Biogeochem. Cy., 27, 1083-1095, https://doi.org/10.1002/2013gb004631, 2013.

Eyre, B. D., Maher, D. T., and Sanders, C.: The contribution of denitrification and burial to the nitrogen budgets of three geomorphically distinct Australian estuaries: Importance of seagrass habitats, Limnol. Oceanogr., 61, 1144-1156, https://doi.org/10.1002/lno.10280, 2016.

Falcón, L. I., Carpenter, E. J., Cipriano, F., Bergman, B., and Capone, D. G.: $\mathrm{N}_{2}$ fixation by unicellular bacterioplankton from the Atlantic and Pacific Oceans: phylogeny and in situ rates, Appl. Environ. Microbiol., 70, 765-770, 2004.

Field, C. B., Behrenfeld, M. J., Randerson, J. T., and Falkowski, P.: Primary production of the biosphere: integrating terrestrial and oceanic components, Science, 281, 237-240, 1998.

Fowler, D., Coyle, M., Skiba, U., Sutton, M. A., Cape, J. N., Reis, S., Sheppard, L. J., Jenkins, A., Grizzetti, B., and Galloway, J. N.: The global nitrogen cycle in the twenty-first century, Philos. T. Roy. Soc. B, 368, 20130164, https://doi.org/10.1098/rstb.2013.0164, 2013.
Fulweiler, R., Brown, S., Nixon, S., and Jenkins, B.: Evidence and a conceptual model for the co-occurrence of nitrogen fixation and denitrification in heterotrophic marine sediments, Mar. Ecol.Prog. Ser., 482, 57-68, 2013.

Fulweiler, R. W., Heiss, E. M., Rogener, M. K., Newell, S. E., LeCleir, G. R., Kortebein, S. M., and Wilhelm, S. W.: Examining the impact of acetylene on $\mathrm{N}$-fixation and the active sediment microbial community, Front. Microbiol., 6, 418, https://doi.org/10.3389/fmicb.2015.00418, 2015.

Galloway, J. N., Aber, J. D., Erisman, J. W., Seitzinger, S. P., Howarth, R. W., Cowling, E B., and Cosby, B. J.: The Nitrogen Cascade, BioScience, 53, 341-356, https://doi.org/10.1641/00063568(2003)053[0341:TNC]2.0.CO;2, 2003.

Garcias-Bonet, N., Marba, N., Holmer, M., and Duarte, C. M.: Effects of sediment sulfides on seagrass Posidonia oceanica meristematic activity, Mar. Ecol.-Prog. Ser., 372, 1-6, 2008.

Garcias-Bonet, N., Arrieta, J. M., de Santana, C. N., Duarte, C. M., and Marbà, N.: Endophytic bacterial community of a Mediterranean marine angiosperm (Posidonia oceanica), Front. Microbiol., 3, 342, https://doi.org/10.3389/fmicb.2012.00342, 2012.

Garcias-Bonet, N., Arrieta, J. M., Duarte, C. M., and Marba, N.: Nitrogen-fixing bacteria in Mediterranean seagrass (Posidonia oceanica) roots, Aquat. Bot., 131, 57-60, https://doi.org/10.1016/j.aquabot.2016.03.002, 2016

Garcias-Bonet, N., Vaquer-Sunyer, R., Duarte, C. M., and Marbà, N.: Warming effect on nitrogen fixation in Mediterranean macrophyte sediments, Biogeosciences Discuss., https://doi.org/10.5194/bg-2018-373, in review, 2018.

Gardner, W. S. and McCarthy, M. J.: Nitrogen dynamics at the sediment-water interface in shallow, sub-tropical Florida Bay: why denitrification efficiency may decrease with increased eutrophication, Biogeochemistry, 95, 185-198, 2009.

Hansen, J. W., Udy, J. W., Perry, C. J., Dennison, W. C., and Lomstein, B. A.: Effect of the seagrass Zostera capricorni on sediment microbial processes, Mar. Ecol.-Prog. Ser., 199, 83-96, https://doi.org/10.3354/meps199083, 2000.

Hemminga, M., Harrison, P., and Van Lent, F.: The balance of nutrient losses and gains in seagrass meadows, Mar. Ecol.-Prog. Ser., 71, 85-96, 1991.

Herbert, R. A.: Nitrogen cycling in coastal marine ecosystems, FEMS Microbiol. Rev., 23, 563-590, 1999.

Holtappels, M., Lavik, G., Jensen, M. M., and Kuypers, M. M.: ${ }^{15} \mathrm{~N}$ labeling experiments to dissect the contributions of heterotrophic denitrification and anammox to nitrogen removal in the $\mathrm{OMZ}$ waters of the ocean, in: Methods in enzymology, Elsevier, Cambridge, Massachusetts, USA, 223-251, 2011.

Howarth, R. W.: Nutrient limitation of net primary production in marine ecosystems, Annu. Rev. Ecol. Syst., 19, 89-110, 1988.

Howarth, R. W. and Marino, R.: Nitrogen as the limiting nutrient for eutrophication in coastal marine ecosystems: evolving views over three decades, Limnol. Oceanogr., 51, 364-376, 2006.

Isobe, K., Koba, K., Ueda, S., Senoo, K., Harayama, S., and Suwa, Y.: A simple and rapid GC/MS method for the simultaneous determination of gaseous metabolites, J. Microbiol. Meth., 84, 4651, 2011a. 
Isobe, K., Suwa, Y., Ikutani, J., Kuroiwa, M., Makita, T., Takebayashi, Y., Yoh, M., Otsuka, S., Senoo, K., and Ohmori, M.: Analytical techniques for quantifying ${ }^{15} \mathrm{~N} /{ }^{14} \mathrm{~N}$ of nitrate, nitrite, total dissolved nitrogen and ammonium in environmental samples using a gas chromatograph equipped with a quadrupole mass spectrometer, Microbes Environ., 26, 46-53, 2011 b.

Kennedy, H., Beggins, J., Duarte, C. M., Fourqurean, J. W., Holmer, M., Marbà, N., and Middelburg, J. J.: Seagrass sediments as a global carbon sink: Isotopic constraints, Global Biogeochem. Cy., 24, GB4026, https://doi.org/10.1029/2010GB003848, 2010.

Kristensen, E., Penha-Lopes, G., Delefosse, M., Valdemarsen, T., Quintana, C. O., and Banta, G. T.: What is bioturbation? The need for a precise definition for fauna in aquatic sciences, Mar. Ecol.-Prog. Ser., 446, 285-302, 2012.

McGlathery, K. J.: Seagrass habitats, in: Nitrogen in the Marine Environment, edited by: Capone, D. G., Bronk, D. A., Mulholland, M. R., and Carpenter, E. J., 2nd Edn., Elsevier Academic Press Inc, 525 B Street, Suite 1900, San Diego, Ca 92101-4495, USA, 2008.

Meyer, R. L., Risgaard-Petersen, N., and Allen, D. E.: Correlation between anammox activity and microscale distribution of nitrite in a subtropical mangrove sediment, Appl. Environ. Microbiol., 71, 6142-6149, 2005.

Moriarty, D. and O'Donohue, M.: Nitrogen fixation in seagrass communities during summer in the Gulf of Carpentaria, Australia, Mar. Freshwater Res., 44, 117-127, https://doi.org/10.1071/MF9930117, 1993.

Nielsen, L. B., Finster, K., Welsh, D. T., Donelly, A., Herbert, R. A., de Wit, R., and Lomstein, B. A.: Sulphate reduction and nitrogen fixation rates associated with roots, rhizomes and sediments from Zostera noltii and Spartina maritima meadows, Environ. Microbiol., 3, 63-71, 2001.

Nowicki, B. L.: The effect of temperature, oxygen, salinity, and nutrient enrichment on estuarine denitrification rates measured with a modified nitrogen gas flux technique, Estuar. Coast. Shelf S., 38, 137-156, 1994.

Pedersen, O., Borum, J., Duarte, C. M., and Fortes, M. D.: Oxygen dynamics in the rhizosphere of Cymodocea rotundata, Mar. Ecol.-Prog. Ser., 169, 283-288, 1998.

Pedersen, O., Colmer, T. D., Borum, J., Zavala-Perez, A., and Kendrick, G. A.: Heat stress of two tropical seagrass species during low tides-impact on underwater net photosynthesis, dark respiration and diel in situ internal aeration, New Phytol., 210, 1207-1218, https://doi.org/10.1111/nph.13900, 2016.

Raitsos, D. E., Pradhan, Y., Brewin, R. J. W., Stenchikov, G., and Hoteit, I.: Remote Sensing the Phytoplankton Seasonal Succession of the Red Sea, PLOS ONE, 8, e64909, https://doi.org/10.1371/journal.pone.0064909, 2013.

Raja, S., Thangaradjou, T., Sivakumar, K., and Kannan, L.: Rhizobacterial population density and nitrogen fixation in seagrass community of Gulf of Mannar, India, J. Environ. Biol., 33, 10331037, 2012.

Salk, K. R., Erler, D. V., Eyre, B. D., Carlson-Perret, N., and Ostrom, N. E.: Unexpectedly high degree of anammox and DNRA in seagrass sediments: Description and application of a revised isotope pairing technique, Geochim. Cosmochim. Ac., 211, 6478, 2017.
Seitaj, D., Schauer, R., Sulu-Gambari, F., Hidalgo-Martinez, S., Malkin, S. Y., Burdorf, L. D., Slomp, C. P., and Meysman, F. J.: Cable bacteria generate a firewall against euxinia in seasonally hypoxic basins, P. Natl. Acad. Sci. USA, 112, 13278-13283, 2015.

Seitzinger, S., Harrison, J., Dumont, E., Beusen, A. H., and Bouwman, A.: Sources and delivery of carbon, nitrogen, and phosphorus to the coastal zone: An overview of Global Nutrient Export from Watersheds (NEWS) models and their application, Global Biogeochem. Cy., 19, 368, https://doi.org/10.1029/2005GB002606, 2005.

Thamdrup, B. and Dalsgaard, T.: Production of $\mathrm{N}_{2}$ through anaerobic ammonium oxidation coupled to nitrate reduction in marine sediments, Appl. Environ. Microbiol., 68, 1312-1318, 2002.

Tibbles, B., Lucas, M., Coyne, V., and Newton, S.: Nitrogenase activity in marine sediments from a temperate saltmarsh lagoon: modulation by complex polysaccharides, ammonium and oxygen, J. Exp. Mar. Biol. Ecol., 184, 1-20, 1994.

van Luijn, F., Boers, P. C., and Lijklema, L.: Comparison of denitrification rates in lake sediments obtained by the $\mathrm{N}_{2}$ flux method, the ${ }^{15} \mathrm{~N}$ isotope pairing technique and the mass balance approach, Water Res., 30, 893-900, 1996.

Vitousek, P. M., Aber, J. D., Howarth, R. W., Likens, G. E., Matson, P. A., Schindler, D. W., Schlesinger, W. H., and Tilman, D. G.: Human alteration of the global nitrogen cycle: sources and consequences, Ecol. Appl., 7, 737-750, 1997.

Voss, M., Bange, H. W., Dippner, J. W., Middelburg, J. J., Montoya, J. P., and Ward, B.: The marine nitrogen cycle: recent discoveries, uncertainties and the potential relevance of climate change, Philos. T. Roy. Soc. B, 368, 20130121, https://doi.org/10.1098/rstb.2013.0121, 2013.

Weikert, H.: Plankton and the pelagic environment, in: Red Sea, edited by: Edwards, A. J. and Head, S. M., Pergamon Press, Oxford 90-111, 1987.

Welsh, D. T.: Nitrogen fixation in seagrass meadows: Regulation, plant-bacteria interactions and significance to primary productivity, Ecol. Lett., 3, 58-71, 2000.

Welsh, D. T.: It's a dirty job but someone has to do it: the role of marine benthic macrofauna in organic matter turnover and nutrient recycling to the water column, Chem. Ecol., 19, 321-342, 2003.

Welsh, D. T., Bourgues, S., deWit, R., and Herbert, R. A.: Seasonal variations in nitrogen-fixation (acetylene reduction) and sulphate-reduction rates in the rhizosphere of Zostera noltii: Nitrogen fixation by sulphate reducing bacteria, Mar. Biol., 125, 619-628, 1996.

Welsh, D. T., Bartoli, M., Nizzoli, D., Castaldelli, G., Riou, S. A., and Viaroli, P.: Denitrification, nitrogen fixation, community primary productivity and inorganic- $\mathrm{N}$ and oxygen fluxes in an intertidal Zostera noltii meadow, Mar. Ecol.-Prog. Ser., 208, 65-77, 2000.

Wilson, S. T., Böttjer, D., Church, M. J., and Karl, D. M.: Comparative Assessment of Nitrogen Fixation Methodologies, Conducted in the Oligotrophic North Pacific Ocean, Appl. Environ. Microbiol., 78, 6516-6523, https://doi.org/10.1128/aem.0114612, 2012.

Yoshinaga, I., Amano, T., Yamagishi, T., Okada, K., Ueda, S., Sako, Y., and Suwa, Y.: Distribution and diversity of anaerobic ammonium oxidation (anammox) bacteria in the sediment of a eu- 
trophic freshwater lake, Lake Kitaura, Japan, Microbes Environ., 26, 189-197, 2011.

Zarnoch, C. B., Hoellein, T. J., Furman, B. T., and Peterson, B. J.: Eelgrass meadows, Zostera marina (L.), facilitate the ecosystem service of nitrogen removal during simulated nutrient pulses in Shinnecock Bay, New York, USA, Mar. Pollut. Bull., 124, 376387, 2017.
Zhou, X., Smith, H., Silva, A. G., Belnap, J., and GarciaPichel, F.: Differential responses of dinitrogen fixation, diazotrophic cyanobacteria and ammonia oxidation reveal a potential warming-induced imbalance of the $\mathrm{N}$ cycle in biological soil crusts, PloS one, 11, e0164932, https://doi.org/10.1371/journal.pone.0164932, 2016. 